\title{
IMPLEMENTASI METODOLOGI PERANCANGAN PERKERASAN COAL HAULING ROAD DI STA KM 37+000 - 37+300 BERDASARKAN MANUAL DESAIN PERKERASAN JALAN 2017 MENGGUNAKAN UKURAN AGREGAT TERTENTU
}

\author{
Geniusman Sidabutar ST IPM ${ }^{1}$, Desyandi Putraldi ST $^{2)}$ \\ ${ }^{1)}$ Superintendent Produksi, PT Lahai Coal \\ ${ }^{2)}$ Kepala Operasi, PT Wasco Site PT Lahai Coal
}

\begin{abstract}
ABSTRAK
Coal hauling road merupakan jalan utama yang dipergunakan untuk mengangkut batubara dari Pit ke Stockpile Port dengan jarak $48 \mathrm{Km}$ menggunakan unit dump truck bermuatan 26 ton hingga 34 ton dengan target produksi 1.000.000 ton pertahun. Unit dump truck yang digunakan masuk ke dalam kategori truck 3 sumbu - sedang, dengan nilai faktor ekivalen beban atau Vehicle Damage Factor (VDF) sesuai dengan tabel dari Manual Perkerasan Jalan 2017. Jumlah lintas harian rata-rata (LHR) semua unit dump truck yang melintas dalam sehari mencapai 270 lintasan sehingga jumlah kumulatif beban gandar standar (CESA) dalam hal ini CESA pangkat 4 sebesar $12.86 \times 10^{6}$ dan CESA pangkat 5 sebesar $17.69 \times 10^{6}$.

Secara visual dan kondisi yang ada california bearing ratio (CBR) tanah dasar coal hauling road lebih besar dari 6\% maka tidak tidak diperlukan perbaikan tanah dasar. Struktur pengerasan berdasarkan ESA5 masuk ke dalam kategori Bagan Desain 3 dimana berdasarkan Bagan Desain 3, desain perkerasan jalan dilakukan dengan menggunakan pondasi agregat kelas A hingga menggunakan asphaltic concrete wearing course (AC WC). Secara aktual Bagan Desain 3 tidak dapat terpenuhi, sebagai alternatif adalah menggunakan Bagan Desain 5 dimana perkerasan jalan menggunakan 3 lapisan, yaitu lapis pondasi agregat kelas A, kelas B dan Burda (lapis penutup berupa laburan dengan ukuran $20 \mathrm{~mm}$ ).

Penerapan perkerasan jalan dengan mengunakan Bagan Desain 5, khususnya penggunaan agregat A di coal hauling road dipilih menggunakan ukuran $10 \mathrm{~mm}-20 \mathrm{~mm}, 20 \mathrm{~mm}-30 \mathrm{~mm}$ dan $30 \mathrm{~mm}-50 \mathrm{~mm}$ sedangkan lapisan burda tidak digunakan. Penggunaan agregat modifikasi ini telah dilakukan di STA KM 37 dengan panjang jalan mencapai 300 meter. Tujuan dari penggunaan agregat modifikasi ini yaitu untuk menjaga traksi roda kendaraan dengan permukaan jalan, mempercepat slippery, mengurangi potensi jalan berdebu dan mengurangi perawatan jalan khususnya penggunaan unit grader.
\end{abstract}

Kata kunci: Coal hauling Road, VDF, LHR, ESA, Manual Desain Perkerasan Jalan, Bagan Desain, Agregat

\begin{abstract}
Coal hauling road is the main road used to transport coal from the Pit to Stockpile Port with a distance of $48 \mathrm{Km}$ using dump trucks capacity 26 - 34 tons with a production target of 1,000,000 tons per year. The dump truck units used fall into the 3 axes - medium truck category, with the value of the Vehicle Damage Factor (VDF) in accordance with the table from the Road Pavement Manual 2017. The average daily traffic count (LHR) of all dump truck units passing in a day reaches 270 passes so that the cumulative number of standard axle loads (CESA) in this case CESA 4 is $12.86 \times 10^{6}$ and CESA 5 is $17.69 \times 10^{6}$.

Visually and the existing condition of California bearing ratio (CBR) of subgrade coal hauling road is greater than 6\%, there is no need for subgrade improvement. Based on ESA5 the hardening structure
\end{abstract}


will use Design Chart 3 category. Based on Design Chart 3 the pavement design is carried out using aggregate foundation class A to using asphaltic concrete wearing course (ACWC). Actually Design Chart 3 cannot be fulfilled, as an alternative is to use Design Chart 5 where the pavement uses 3 layers, namely the aggregate foundation layers of class A, class B and Burda (the covering layer is a $20 \mathrm{~mm}$ diameter).

The application of pavement using Design Chart 5, specifically the use of aggregate $A$ in coal hauling road is chosen using sizes $10 \mathrm{~mm}-20 \mathrm{~mm}, 20 \mathrm{~mm}-30 \mathrm{~mm}$ and $30 \mathrm{~mm}-50 \mathrm{~mm}$ while the burda layer is not used. The use of this modified aggregate has been carried out at STA KM 37 with a road length of up to 300 meters. The purpose of using this modified aggregate is to maintain vehicle wheel traction with the road surface, accelerate slippery, reduce the potential for dusty roads and reduce road maintenance, especially the use of grader units.

Keywords: Coal hauling Road, VDF, LHR, ESA, Road Pavement Design Manual, Design Chart, Aggregate

\section{A. PENDAHULUAN}

Latar belakang penulisan makalah ini adalah karakteristik coal hauling road yang kompleks, ketersediaan material agregat yang terbatas, minimum road maintenance unit serta faktor keselamatan khususnya jalan berdebu dan jalan licin. Adapun tujuan dari penulisan ini adalah untuk mendapatkan metode perkerasan jalan yang sesuai dengan karakteristik di coal hauling road serta pertimbangan ketersediaan material di lokasi dengan tetap mengacu kepada prinsip produktivitas, efektivitas dan faktor keselamatan. Pendekatan pemecahan masalah yang digunakan merupakan implementasi metodologi perancangan perkerasan jalan yang terdiri dari dari pengamatan visual, pengambilan data, pengamatan road maintenance dan perhitungan menggunakan Manual Desain Perkerasan Jalan 2017.

\section{B. METODOLOGI PENELITIAN}

Metode penelitian yang digunakan berdasarkan metode perkerasan perancangan perkerasan jalan dapat dilihat pada gambar 1, khususnya berdasarkan metode Manual Desain Perkerasan Jalan 2017. Berdasakan metode ini ada beberapa tahapan yang dilakukan selama penelitian yaitu pengamatan visual berupa pengambilan dokumentasi kondisi jalan sebelum dilakukan perkerasan, pengambilan data volume lalu lintas harian (LHR), pengamatan road maintenance yang dilakukan, pengamatan kondisi jalan pada saat kondisi hujan dan kering. Tahapan selanjutnya yang berkaitan dengan beban jalan adalah perhitungan atau penentuan nilai umur rencana jalan, faktor distribusi lajur, Vehicle Damage Factor (VDF), perhitungan ESA4 dan ESA5. Tahapan perhitungan daya dukung subgrade atau nilai California Bearing Ratio (CBR) dilakukan dengan dua pendekatan yaitu referensi dan uji di lapangan. Tahapan selanjutnya adalah penentuan Bagan Desain berdasarkan hasil perhitungan yang telah dilakukan.

Hasil perancangan yang dihasilkan berdasarkan metode yang digunakan selanjutnya dilakukan uji untuk memastikan hasil perancangan tersebut dapat diterapkan di lapangan. Adapun uji ini dilakukan dengan pendekatan terapan dan teoritis yang didasari pengalaman dan aktual di lapangan dengan tetap berdasarkan tujuan yang ingin dicapai. 


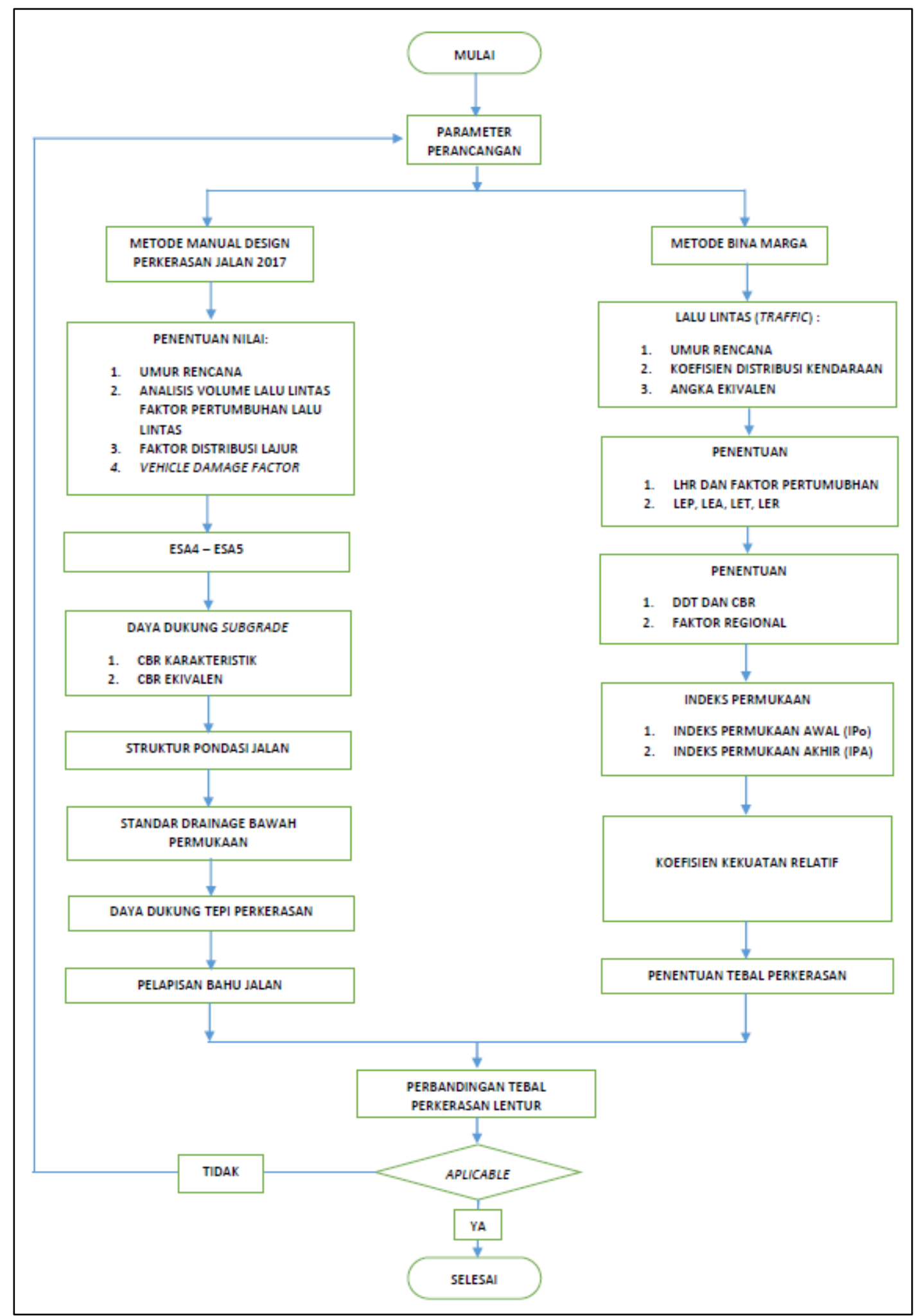

Gambar 1. Metodologi Perancangan Perkerasan Jalan 


\section{HASIL DAN PEMBAHASAN}

Coal hauling road memiliki panjang $48 \mathrm{KM}$ yang terbagi menjadi 4 zona dengan karakteristik yang berbeda. Zona 1 merupakan coal hauling road yang hanya dilalui operasional PT Lahai Coal serta mitra kerja, zona 2 merupakan coal hauling road perusahaan tambang batubara lain, zona 3 merupakan coal hauling road yang digunakn bersama perusahaan tambang lain serta masyarakat dan zona 4 merupakan coal hauling road yang berdekatan dengan pemukiman warga. Impelementasi penelitian ini dilakukan di Zona I dengan segmen jalan KM 37+000 hingga KM 37+300.

Umur rencana coal haulimg road yang telah ditentukan yaitu 10 tahun dengan jumlah lalu lintas harian rata-rata (LHR) khusus unit coal hauling PT Lahai Coal di tahun 2018 sebesar 270 sedangkan secara total dapat dilihat pada tabel 1. Rencana jumlah unit coal hauling PT Lahai Coal dalam dua tahun berikutnya terjadi penambahan unit coal hauling.

Tabel 1. Perhitungan LHR dan ESA4 Tahun 2020

\begin{tabular}{|c|c|c|c|c|c|c|c|}
\hline Jenis Kendaraan & LHR ( 2 arah) & LHR 2018 & LHR 2020 & VDF4 Faktual & VDF4 Normal & ESA4 18 & ESA4 20 \\
\hline 1 & 2 & 3 & 4 & 5 & 6 & 7 & 8 \\
\hline Bus kecil & 2 & 2 & 2 & 1.0 & 1.0 & 730 & 7,867 \\
\hline Bus besar & 10 & 10 & 10 & 0.6 & 0.6 & 2,009 & 21,635 \\
\hline Truk 2 sumbu - cargo ringan & 8 & 8 & 8 & 4.8 & 3.4 & 14,023 & 106,993 \\
\hline Truk 3 sumbu - sedang & - & - & - & 9.6 & 4.2 & - & - \\
\hline Perusahaan Tambang Batubara Lain & 301 & 301 & 365 & 9.6 & 4.2 & $1,056,634$ & $6,030,137$ \\
\hline PT Lahai Coal & 270 & 270 & 271 & 9.6 & 4.2 & 947,955 & $4,477,170$ \\
\hline \multirow[t]{3}{*}{ Truk 4 sumbu - trailer } & 6 & 6 & 6 & 11.7 & 7.0 & 25,636 & 165,209 \\
\hline & & & & & & $2,046,987$ & $10,809,010$ \\
\hline & & & & & & CESA4 (18-20) & $12,855,997$ \\
\hline
\end{tabular}

Tabel 2. Perhitungan ESA5 Tahun 2020

\begin{tabular}{|c|c|c|c|c|c|c|c|}
\hline Jenis Kendaraan & LHR (2 arah) & LHR 2018 & LHR 2020 & VDF5 Faktual & VDF5 Normal & ESA5 18 & ESA5 20 \\
\hline 1 & 2 & 3 & 4 & 5 & 6 & 7 & 8 \\
\hline Bus kecil & 2 & 2 & 2 & 1.0 & 1.0 & 730 & 7,867 \\
\hline Bus besar & 10 & 10 & 10 & 0.5 & 0.5 & 1,826 & 19,668 \\
\hline Truk 2 sumbu - cargo ringan & 8 & 8 & 8 & 8.5 & 4.7 & 24,832 & 147,902 \\
\hline Truk 3 sumbu - sedang & - & - & - & 17.7 & 5.4 & - & - \\
\hline Perusahaan Tambang Batubara Lain & 301 & 301 & 365 & 17.7 & 5.4 & $1,948,168$ & $7,753,033$ \\
\hline PT Lahai Coal & 270 & 270 & 271 & 17.7 & 5.4 & $1,747,793$ & $5,756,362$ \\
\hline \multirow[t]{3}{*}{ Truk 4 sumbu - trailer } & 6 & 6 & 6 & 20.4 & 10.2 & 44,698 & 240,733 \\
\hline & & & & & & $3,768,048$ & $13,925,564$ \\
\hline & & & & & & CESA5 (18-20) & $17,693,612$ \\
\hline
\end{tabular}

Perhitungan ESA4 dan ESA5 didasarkan pengamatan LHR tahun 2018 serta proyeksi tahun 2020 dengan tingkat pertumbuhan khususnya unit coal hauling perusahaan tambang batubara lainnya sebesar $10 \%$ pertahun. Sedangkan untuk nilai VDF menggunakan nilai yang mengacu pada kondisi di Kalimantan dapat dilihat pada tabel 3. Unit coal hauling dikategorikan ke dalam jenis kendaraan Truk 3 sumbu -sedang.

Berdasarkan nilai ESA4 yang telah dihitung maka struktur perkerasan yang digunakan dapat dilihat pada Gambar 2. Dimana struktur perkerasan yang disarankan adalah Bagan Desain 3, dengan kondisi lapangan yang tidak dapat diaplikasikan maka Bagan Desain 3 tidak dapat digunakan sehingga dicari Bagan Desain yang bisa diaplikasikan yaitu Bagan Desain 5. 
Tabel 3. Nilai VDF Kalimantan

\begin{tabular}{lrrrr}
\hline \multirow{2}{*}{ Jenis Kendaraan } & \multicolumn{4}{c}{ Kalimantan } \\
& Beban Faktual & \multicolumn{2}{c}{ Normal } \\
& \multicolumn{1}{c}{ VDF4 } & VDF5 & VDF4 & \multicolumn{1}{c}{ VDF5 } \\
\hline Bus kecil & 1.00 & 1.00 & 1.00 & 1.00 \\
Bus besar & 0.55 & 0.50 & 0.55 & 0.50 \\
Truk 2 sumbu - cargo ringan & 4.80 & 8.50 & 3.40 & 4.70 \\
Truk 3 sumbu - ringan & 9.90 & 18.30 & 4.10 & 5.30 \\
Truk 3 sumbu - sedang & 9.60 & 17.70 & 4.20 & 5.40 \\
Truk 4 sumbu - trailer & 11.70 & 20.40 & 7.00 & 10.20 \\
Truk 5 sumbu - trailer & 8.20 & 14.70 & 4.00 & 5.20 \\
Truk 6 sumbu - trailer & 13.50 & 22.90 & 9.80 & 15.00 \\
\hline
\end{tabular}

\begin{tabular}{|c|c|c|c|c|c|c|}
\hline \multirow{2}{*}{ Struktur Perkerasan } & \multirow{2}{*}{$\begin{array}{l}\text { Bagan } \\
\text { desain }\end{array}$} & \multicolumn{5}{|c|}{$\begin{array}{l}\text { ESA (juta) dalam } 20 \text { tahun } \\
\text { (pangkat } 4 \text { kecuali ditentukan lain) }\end{array}$} \\
\hline & & $0-0,5$ & $0,1-4$ & $>4-10$ & $>10-30$ & $>30-200$ \\
\hline $\begin{array}{l}\text { Perkerasan kaku dengan lalu } \\
\text { lintas berat (di atas tanah } \\
\text { dengan } \mathrm{CBR} \geq 2,5 \% \text { ) }\end{array}$ & 4 & - & - & 2 & 2 & 2 \\
\hline $\begin{array}{l}\text { Perkerasan kaku dengan lalu } \\
\text { lintas rendah (daerah } \\
\text { pedesaan dan perkotaan) }\end{array}$ & $4 \mathrm{~A}$ & - & 1,2 & - & - & - \\
\hline $\begin{array}{l}\text { AC WC modifikasi atau SMA } \\
\text { modifikasi dengan CTB (ESA } \\
\text { pangkat 5) }\end{array}$ & 3 & - & - & - & 2 & 2 \\
\hline $\begin{array}{l}\text { AC dengan CTB (ESA } \\
\text { pangkat 5) }\end{array}$ & 3 & - & - & - & 2 & 2 \\
\hline $\begin{array}{l}\text { AC tebal } \geq 100 \mathrm{~mm} \text { dengan } \\
\text { lapis fondasi berbutir (ESA } \\
\text { pangkat 5) }\end{array}$ & $3 B$ & - & - & 1,2 & 2 & 2 \\
\hline $\begin{array}{l}\text { AC atau HRS tipis diatas } \\
\text { lapis fondasi berbutir }\end{array}$ & $3 \mathrm{~A}$ & - & 1,2 & - & - & - \\
\hline $\begin{array}{l}\text { Burda atau Burtu dengan } \\
\text { LPA Kelas A atau batuan asli }\end{array}$ & 5 & 3 & 3 & - & - & - \\
\hline Lapis Fondasi Soil Cement & 6 & 1 & 1 & - & - & - \\
\hline $\begin{array}{l}\text { Perkerasan tanpa penutup } \\
\text { (Japat, jalan kerikil) }\end{array}$ & 7 & 1 & - & - & - & - \\
\hline \multicolumn{7}{|l|}{ Catatan: } \\
\hline \multicolumn{7}{|l|}{ Tingkat kesulitan: } \\
\hline \multicolumn{7}{|c|}{$\begin{array}{l}\text { 1-kontraktor kecil - medium; } \\
\text { 2-kontraktor besar dengan sumber daya yang memadai; } \\
3 \text { - membutuhkan keahlian dan tenaga ahli khusus -kontraktor spesialis Burtu / Burda. }\end{array}$} \\
\hline
\end{tabular}

Gambar 2. Struktur Perkerasan

Sesuai dengan Bagan Desain 5, lapisan material yang disarankan untuk digunakan adalah pondasi agregat kelas A dengan ketebalan 340 mm, dimana karakteristik agregat kelas A ini dapat dilihat pada Tabel 4. 


\begin{tabular}{|c|c|c|c|c|c|}
\hline & \multicolumn{5}{|c|}{ STRUKTUR PERKERASAN } \\
\hline & SD1 & SD2 & SD3 & $\mathrm{SD} 4^{3}$ & $\mathrm{SD} 5^{3}$ \\
\hline & \multicolumn{5}{|c|}{$\begin{array}{l}\text { Beban sumbu } 20 \text { tahun pada lajur desain } \\
\left({ }^{\left(E S A 4 \times 10^{5}\right)}\right.\end{array}$} \\
\hline & $<0,1$ & $0,1-0,5$ & $>0,5-4$ & $>4-10$ & $>10-30$ \\
\hline & \multicolumn{5}{|c|}{ Ketebalan lapis perkerasan (mm) } \\
\hline Burda & \multicolumn{5}{|c|}{ Ukuran agregat nominal $20 \mathrm{~mm}$} \\
\hline Lapis Fondasi Agregat Kelas $\mathrm{A}^{2}$ & 200 & 250 & 300 & 320 & 340 \\
\hline $\begin{array}{l}\text { Lapis Fondasi Agregat kelas A, atau } \\
\text { kelas B, atau kerikil alam, atau } \\
\text { stabilisasi dengan CBR }>10 \% \text {, pada } \\
\text { subgrade dengan CBR } \geq 5 \% 2,5\end{array}$ & 100 & 110 & 140 & 160 & 180 \\
\hline
\end{tabular}

Gambar 3. Bagan Desain 5

Tabel 4. Persayarata Lapis Pondasi Agregat

\begin{tabular}{|c|c|c|c|}
\hline SIFAT-SIFAT & KELAS A & KELAS B & KELAS C \\
\hline Abrasi dari Agregat Kasar (SNI 03-2417-1990) & Maks. $40 \%$ & Maks. $40 \%$ & Maks. $40 \%$ \\
\hline $\begin{array}{l}\text { Indek Plastis (SNI-03-1966-1990) dan (SNI-03-1967- } \\
1990)\end{array}$ & Maks. 6 & Maks. 6 & $4-9$ \\
\hline $\begin{array}{l}\text { Hasil kali Indeks Plastisitas dengan \% Lolos Ayakan } \\
\text { No.200 }\end{array}$ & Maks. 25 & - & - \\
\hline Batas cair (SNI 03-1967-1990) & Maks. 25 & Maks. 25 & Maks. 25 \\
\hline $\begin{array}{l}\text { Gumpalan Lempung dan Butir-butir Mudah Pecah } \\
\text { dalam Agregat (SNI-03-4141-1996) }\end{array}$ & o\% & Maks. $1 \%$ & Maks. $1 \%$ \\
\hline CBR (SNI 03-1744-1989) & Min. $90 \%$ & Min. $65 \%$ & Min. $35 \%$ \\
\hline $\begin{array}{l}\text { Perbandingan persen lolos \#200 dengan persen lolos } \\
\#_{40}\end{array}$ & Maks. 2/3 & Maks. 2/3 & Maks. 2/3 \\
\hline
\end{tabular}

Nilai CBR untuk subgrade didapatkan berdasarkan uji DCP dilapangan dapat dilihat pada grafik di Gambar 4.

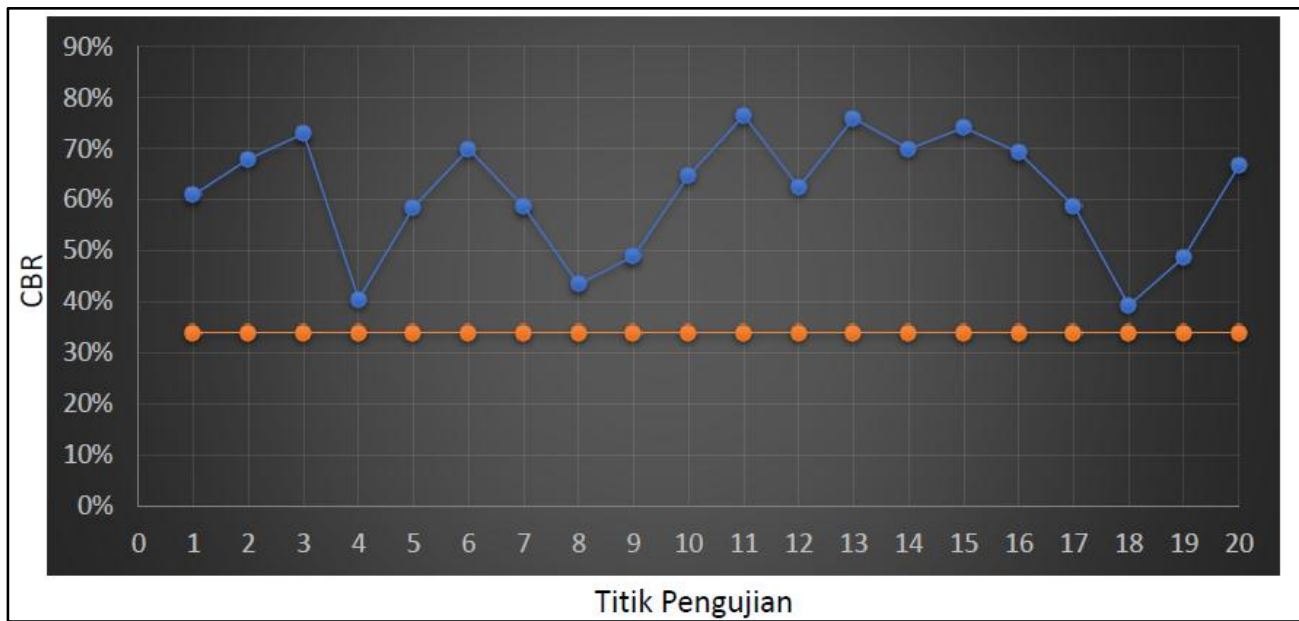

Gambar 4. Nilai CBR Lapangan Berdasarkan Uji DCP

Berdasarkan data hasil perhitungan serta pengujian di lapangan maka metode yang disarankan adalah sesuai dengan Bagan Desain 5. Hasil ini selanjutnya dilakukan review internal terkait pengaplikasian di lapangan berdasarkan pendekatan terapan dan teoritis yang didasari pengalaman dan aktual di 
lapangan, Lapisan pondasi agregat A yang disarankan cenderung memiliki distribusi dengan ukuran agregat persen lolos \#200 mencapai 2/3. Berdasarkan pengamatan dilapangan kelemahan penggunaan material ini adalah material mudah lepas, material menjadi sumber debu dan terbawa erosi hujan sehingga diperlukan pemilihan ukuran agregat yang lebih aplikatif di lapangan serta mudah menjadi slippery material pada saat kondisi hujan.

Pemilihan material agregat tertentu didasarkan pada tujuan yang ingin dicapai, yaitu tetap terjaganya traksi antara roda unit kendaraan dan permukaan jalan, mempercepat slippery, mengurangi potensi debu dan mengurangi perawatan jalan. Material agregat yang digunakan pada penelitian ini memiliki ukuran $10 \mathrm{~mm}-20 \mathrm{~mm}, 20 \mathrm{~mm}-30 \mathrm{~mm}$ dan $30-50 \mathrm{~mm}$ serta ketebalan $10 \mathrm{~cm}$ dengan distribusi dapat dilihat pada gambar 6.

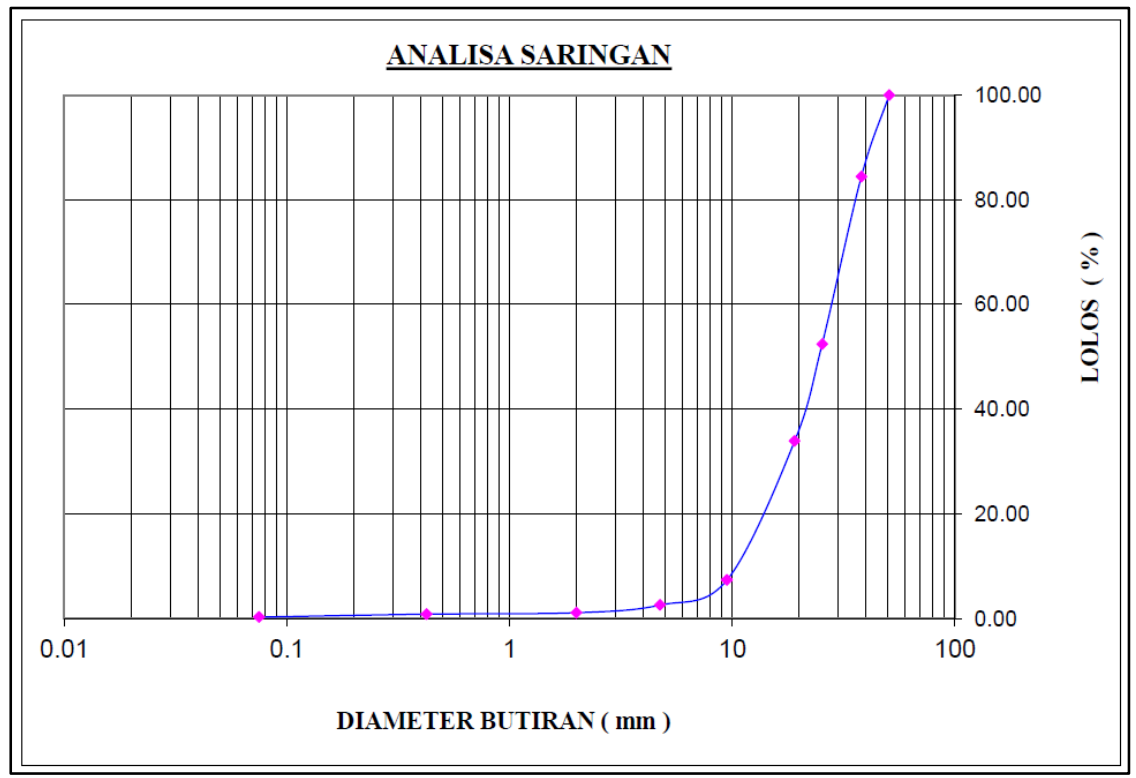

Gambar 6. Distribusi Agregat

Komposisi agregat ini terdiri dari $97.45 \%$ material gravel, $229 \%$ material sand, $0.26 \%$ material clay/slit dengan perbandingan person lolos ayakan \#200 sebesar $0.32 \%$. Berat jenis rata-rata material ini sebesar 2.77 ton/m3 dengan kadar air rata-rata sebesar 4.42\% dan nilai Los Angeles Abrasi 14.51\% serta nilai CBR dapat dilihat pada Gambar 7.

Hasil perkerasan jalan dengan menggunakan material yang ditentukan selanjutnya dilakukan observasi secara berkala dengan hasil pengamatan yang menunjukkan beberapa kekurangan dan kelebihannya. Dimana kekurangan dari penggunaan material ini lebih pada faktor pemadatan dan segregasi dikarenakan material yang berukuran kurang dari $10 \mathrm{~mm}$ hanya mencapai $10 \%$ sehingga diperlukan penghamparan yang lebih merata oleh unit grader serta kegiatan compact yang lebih banyak. Kelebihan dari penggunaan material ini adalah sebagaimana tujuan yang ingin dicapai. 


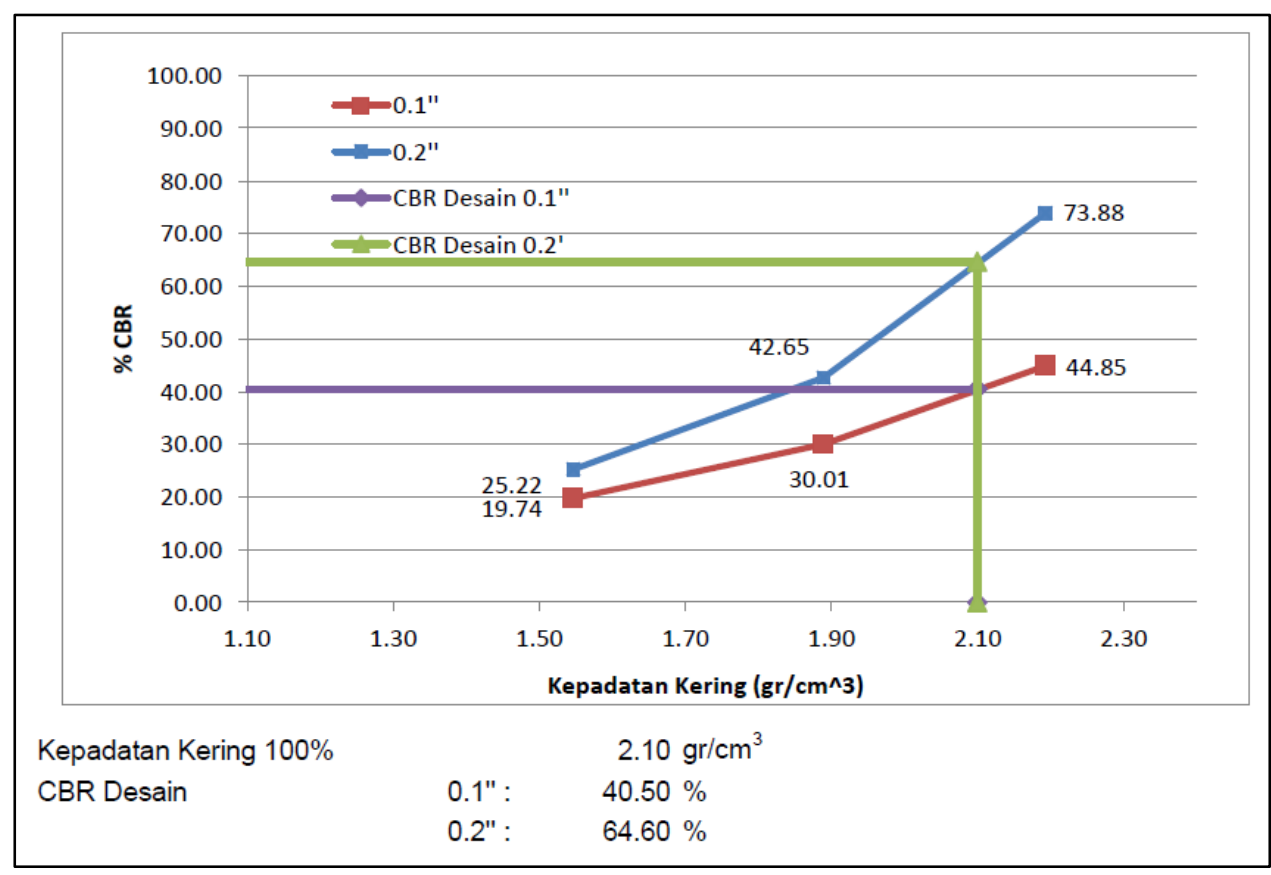

Gambar 8. Grafik CBR Terhadap Kepadatan Kering
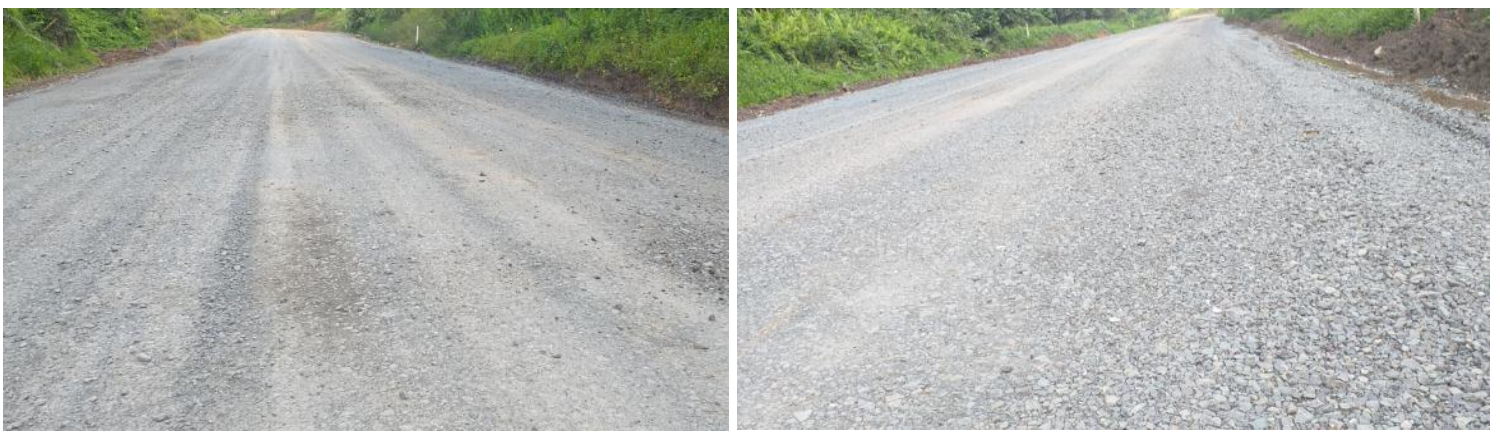

Gambar 9. Kondisi Permukan Jalan Bagian Tengah (kiri) dan Bagian Bahu Jalan (Kanan)

\section{KESIMPULAN}

Penggunaan material agregat sebagaimana hasil yang didapatkan berdasarkan perhitungan menunjukkan struktur perkerasan jalan menggunakan Bagan Desain 3. Dikarenakan dengan kondisi serta ketersediaan material yang ada selanjutnya dilakukan pemilihan Bagan Desain 5 dengan menggunakan material agregat yang lebih aplikatif di lapangan sesuai dengan tujuan yang ingin dicapai. Penggunaan material agregat tertentu yang telah diterapkan menunjukkan bahwa masih ada kekurangan dari penggunaan material ini khususnya faktor pemadatan dan segregasi antar ukuran material sedangkan kelebihan dari penggunaan material ini yaitu traksi antara roda kendaraan dan permukaan jalan, mempercepat slippery, mengurangi potensi jalan berdebu dan mengurangi perawatan jalan khususnya penggunaan unit grader. Penggunaan material agregat ini masih perlu dilakukan kajian guna mendapatkan hasil yang lebih optimal khususnya distribusi ukuran yang digunakan. 


\section{UCAPAN TERIMA KASIH}

Ucapan terima kasih ini kami tujukan kepada semua pihak yang telah membantu sehingga kegiatan penelitian ini berjalan dengan lancar, khususnya kepada KTT PT Lahai Coal dan Manajemen, PT Wasco serta keluarga tercinta.

\section{DAFTAR PUSTAKA}

Geniusman Sidabutar (2017), Prosiding TPT XXVI Implementasi TARP Coal Hauling Guna MencegahTerjadinya Insiden di PT Lahai Coal, PERHAPI, Balikpapan, 372-277.

Geniusman Sidabutar (2018), Prosiding TPT XXVII dan Kongres X PERHAPI 2018 Metodologi Perancangan Jalan Angkut Batubara Dari Aspek Sipil dan Manajemen Keselamatan, PERHAPI, Jakarta.

Manual Design Pekerasan Jalan 2017 Nomor 04/SE/Db/2017 Kementrian Pekerjaan Umum dan Perumahan Rakyat (2017), Jakarta

Pedoman Jalan Angkut Batubara Di SHR (2018), PT Lahai Coal, 13 - 97. 
PROSIDING TPT XXVIII PERHAPI 2019 